\title{
The Phenomenal and the Cultural in Contemporary Paintings from Indian Diaspora
}

\author{
Asmita Sarkar \\ PhD Candidate, Manipal Academy of Higher Education. ORCID: oooo-00o2-2024-5553 \\ Email: asmita.sarkar@srishti.ac.in
}

\begin{abstract}
Contemporary painting is a complex practice that incorporates elements of different media and bear diverse historical and cultural influences. Contemporary painting from South-East Asian diaspora is no less different. In this paper an attempt has been made to analyze a few contemporary painters' work in light of phenomenological theory. Merleau-Ponty's $(1993,2004,2008)$ theory of embodiment and phenomenology of perception has been used to show how the fusion of material exploration, embodied engagement with the lived environment, and knowledge of art-historical and contemporary trend results in creation of painting. It was also shown that the artists discussed are adept at combining cultural and sensual components in their painting thus creating works of art that has a broad cross-cultural appeal. It was argued that a theoretical lens that pays due attention to material and sensual aspects of art can open-up new horizon of analysis.
\end{abstract}

Keywords; Contemporary painting, phenomenology, painting from India

Painting has a special status in art history, and a rich tradition of historical and theoretical writing has been devoted to several formal (compositional, stylistic) and cultural (narrative, semiotic) aspects of painting. But from 1970 with the advent of post-modernism and dematerialization of art, painting as a genre has seen a relative lack of interest from theorists and academics. In the last two decades this situation has changed, painting as a medium is more vibrant than ever. Contemporary painting can be about abstraction, process, social commentary, appropriation and response to new media. Painting can be metaphorically many things in its use of material and space: it can be sculptural (soft sculpture,) site specific and immersive. But contemporary artwriting, especially the writing on South-East Asian art, the focus inevitably falls on several cultural and political aspects that encircle the context of the work of art. While the sensual and material appeal of the work takes a relative back-step. Paul Crowther in his book Phenomenology of the Visual Arts (2009) raised the concern that in much of recent art history and art theoretical writing and conceptualization of artistic process, material and artist's skill is relegated to a position of minor importance. This can result in a reductionist interpretation of art (Crowther 2009, 13.) I agree with Crowther that reducing the interpretation of art to one single political narrative does not help in advancement of art-theory. None the less it should be stated emphatically that each of these political narrative has its own relevance and artists being a social being is always influenced by the political narrative. There are a few interesting and promising works are coming out which looks at the interaction between formal and political aspects in visual art. For example, The Thirteenth Place: Positionality as Critique in the Art of Navjot Altaf,

(C) AesthetixMS 2020. This Open Access article is published under a Creative Commons Attribution Non-Commercial 4.0 International License (http://creativecommons.org/licenses/by-nc/4.0/), which permits non-commercial re-use, distribution, and reproduction in any medium, provided the original work is properly cited. For citation use the DOI. For commercial re-use, please contact editor@chitrolekha.com 
(2016) authored by cultural theorist and curator Nancy Adajania looks at the aesthetic dimension of political art. In this paper I like to bring attention to the material and sensual aspects of contemporary painting as it co-exists with the cultural and political. In some contemporary painting practice, the material comes together with specific cultural elements and becomes meaningful and aesthetically appealing. The lens I am picking for analyzing these works of art is phenomenology, focusing on French philosopher Merleau-Ponty, most noted for his work on phenomenology of embodiment and perception. A phenomenological interpretation can accommodate different narratives and lay open the interaction of different political, social, material, and sensual elements in painting. In this analysis I aim to show that culturally specific and bodily-material dimensions of painting come together in works by painters from south-east Asian diaspora. Noted contemporary curator Hans Ulrich Obrist has an interesting opinion about painting and its resurgence in contemporary art world. Obrist states that "They're [paintings are] very dynamic things - they come, they go, they approach, they recede, they disappear-and that's because they are pure feeling, like a fog or a cloud" (Goldstein 2016). Many curatorial writings and artists' statements accompanying contemporary paintings give prevalence to directness of experience (both the viewer and the maker) and sensory reality. This vital characteristics of contemporary painting alluded to by Obrist is evident in many young painter's work from Indian diaspora.

Many modernist and contemporary painters' artists' statements and documents mention the importance of material exploration and body's engagement with it. But reflection about material and sensory engagement, only occupy a passing reference in documents of modernist paintings when it comes to its theorization. One of the most respected and prolific art-historian James Elkins (2000) in his ambitious book What Painting Is. states that art historians and theorists start theorizing painting only as a finished work, and their main analysis focuses on the cultural and symbolic aspects of the forms depicted. Theorists discuss when these are displayed in gallery and museum. They generally leave out the messy part of the creation of painting in the studio. In contemporary art history and theory, the sensory and material dimension of artistic process rarely takes the central position of enquiry. In the same book Elkin's suggests that Merleu-Ponty's writing on phenomenology of painting may be employed to bring theoretical attention to the sensual and visual elements in painting. The importance of the sensory dimension of material is not lost on practicing artists. The recurring theme of how material or immaterial an object of art is often surfaces in artist's personal narrative. Contemporary paintings coming from South-East Asian diaspora is rich in innovative use of material and juxtaposition of stylistic conventions. In this paper I am substantiating the argument that the appeal of many contemporary paintings do not only come from symbolism, cultural context and the object represented but also from the use of materials, artist's gesture, and ways in which the artist gives shapes to her ideas. The artist as an embodied being expresses her lived experience of a specific cultural and geographical setting though choice of material. Thus sometimes in abstract painting the formal and cultural aspects interact. In the painting interaction of artist's gesture, materials, and the subject matter interact to create an engaging object. In fact, most good art is unique because of this complex interaction. In the next section I want to analyse a few contemporary painter's works focusing on their process. 


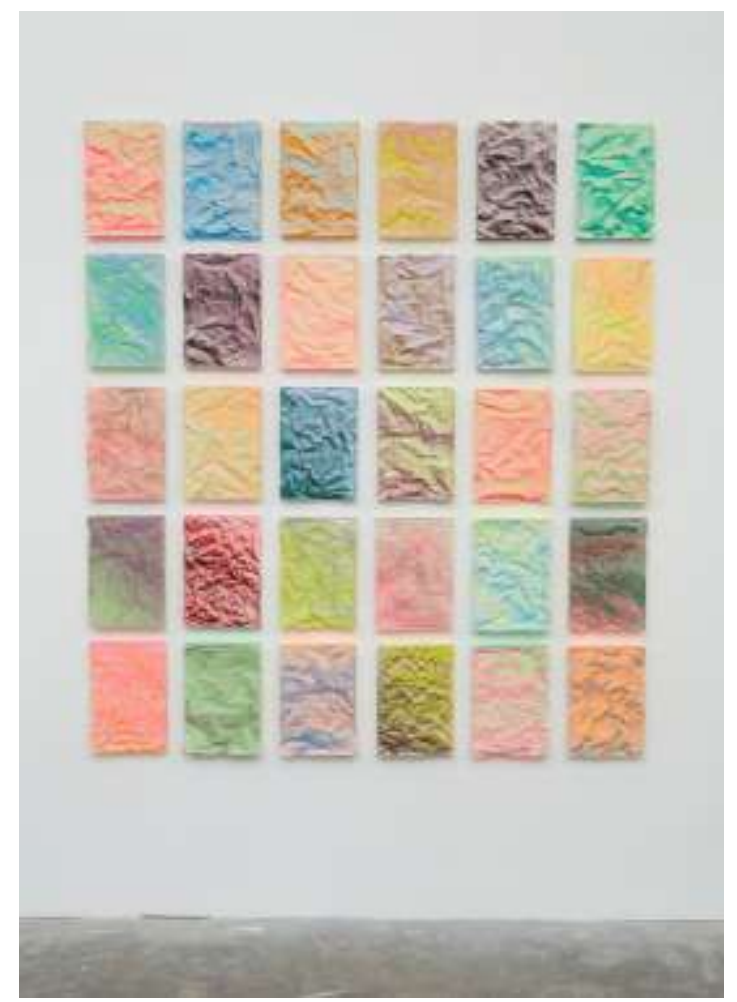

Fig 1 Rana Begum, No. 897 Casts, 2019, Jesmonite,

Fig I. is a painting by British-Bangladeshi artist- Rana Begum. Born in Bangladesh in 1977, she now works from London. She recently held many exhibitions in India and Middle-East. Her works capture light as an abstract temporal and sensorial entity, displayed in minimalist paintings and sculptural installations. Materials determine Rana Begum's works. Begum grew up in Bangladesh and her religious experience in a conservative Muslim family influenced her minimalist aesthetic and her works that takes inspiration from geometric abstraction that are of distinctly Islamic style. She works across media- sculpture, installation, and painting. In this paper I am focusing on her paintings, specifically the surface of her paintings. The colour scheme she adopts for her paintings and installations are influenced by the vivid palette of Bollywood. Indeed, the juxtaposition of red, pink, green, and shimmering of gold is a unusual choice for minimalist geometrically abstract work. Several embodied and experiential elements have seamlessly merged with elegance in form in her work. Some critics may express the viewpoint that her works are conceptually thin, but this opinion points to the prevalent trend in art-criticism to separate conceptual from embodied element. This may not be the most fruitful way of interpreting contemporary practices. The spray painted surface of Jasmonite cast is the articulation of her experience of the undulating surface of water: as she recounts in an interview in architectural digest (Shankar 2019). She says that most of the artist's spaces where she has taken up a residency were situated near water bodies, and the fleeting light reflecting on the surface made an impression on her. The experiential and embodied elements in her work do not escape critics either. Pooja Savanshukha (2019) writes in Hindu about Rana Begum's work highlighting the sensual and the sensory. Savanshukha highlights that Begum's work is not only a condensation of a minimalist visual language but these "conjure an environment that privileges phenomenological experience" In the same news-paper article Savanshukha narrates Begum's inspirations: her love of coasts, weaved-surface, fishing nets and the vibrant colours of Bollywood. All these elements from her growing up years in Bangladesh, entrenched in her memory, seep into 
her works. The review generously comments on the material sensuality of Begum' resplendent works, but finally falls into the prevalent trend of subtly dichotomizing the intellect and the sensual. As Savanshukha writes "While most contemporary art emphasizes the cerebral, Begum's works robustly return attention to our senses." This statement ignores the fact that Begum's artistic practice is no less conceptual than any other. The way she captured fleeting sensation through material manipulation is a testament to coming together of different conceptual and bodily faculties. The surface containing minimalistic gestural traces that carries personal memories are also informed by language of gestural abstraction and minimalist composition. One way of theorizing these canvases can be by explaining it in terms of phenomenological reduction. The tightly composed pattern of the canvas invites the viewer into an inward meditative experience. These express a visceral reality and are instances of phenomenological reduction of some kind: an intensely compressed visual field, communicating lived experience though sensory realities. Phenomenological reduction is a meditative method of bracketing experience and looking inward, originally proposed by Edmund Husserl, widely considered as father of Western phenomenology. Husserl's concept of phenomenological method is somehow aligned with his idea of transcendental idealism and proposes a negation of empirical method of science. MerleauPonty has dissociated with many of Husserl's methods, especially Husserl's insistence on negating any empirical or scientific method. Merleau-Ponty (2004) was influenced by the empirical methods of his contemporary psychologists and existentialists. The concept of (Heidegarian) Being in the world was pivotal for him. But Merleau-Ponty did not completely reject the idea of the phenomenological reduction, termed epoche by Husserl. He combined it with existential and empirical approaches and developed his unique phenomenology (Smith 2005). Painting being a bound flat surface covered in patches of paint, seemed to be a bracketed phenomenon where the viewers and the painters could reflect upon their consciousness. But Merleau-Ponty would also agree that the painted surface is a created space where painter's embodied lived existence is reflected and solidified, and the border of the bound canvas is not a phenomenal space detached from the real world. The painter's body and hand that gives shapes to the painting along with the viewer's embodied presence observing the painting are bodies co-situated in the world. Their perceptual experience is always in a state of indeterminate flux. Between the painter and the viewer comes the material of the painting. And in Begum's the colour and the textures of her materials transcends the boundary between material and conceptual.

One of the most recognizable contemporary artist Subodh Gupta's early paintings serves as an example of how the sensuous texture of materials and composition can add new layers of meaning to art-objects that are already fraught with cultural and political meaning. Critical and curatorial writing on Gupta's work often focuses on the symbolism of Indian urban identities, often ignoring the skilled material manipulation by the artist that makes his works appealing. Subodh Gupta (born in 1964) is an Indian contemporary artist based in New Delhi. Trained as a painter, he went on to experiment with a variety of media. His installations are a direct extension of his painting practice. According to critics, his works oscillate between the universal and regional in their modes of address. Medium, materiality, and structural composition in his paintings and installations are the most important aspects in his oeuvre that are relevant to this paper. He frequently paints and uses steel vessels commonly used by urban Indian middle class. The fact that he uses symbols of Indian urban identity is as important as the compositional aesthetic of his work. Symbolic values are ever present in his work, but more than symbol and identity politics is at play. What makes his paintings and installations visually spectacular is the play between forms and shapes and the materiality of the composition. Gupta compares his individual take on the structure of each unique vessel to the ritual of palm reading. Allie Biswas 
writes for Glass magazine's review of Subodh Gupta's show "Invisible Reality” at Houser and Wirth, London on February 2016. Biswas appreciates Gupta's attention to the structure of each vessel, their distinct patinas, and the tinges of colour with which he weaves an inner narrative hidden in the pots and containers (Biswas 2016). The theme of cosmos comes back over and over again in many of his works. Let's take a closer look at the progress in his works from early figurative paintings of steel utensils to their transformation into abstract cosmic installations.
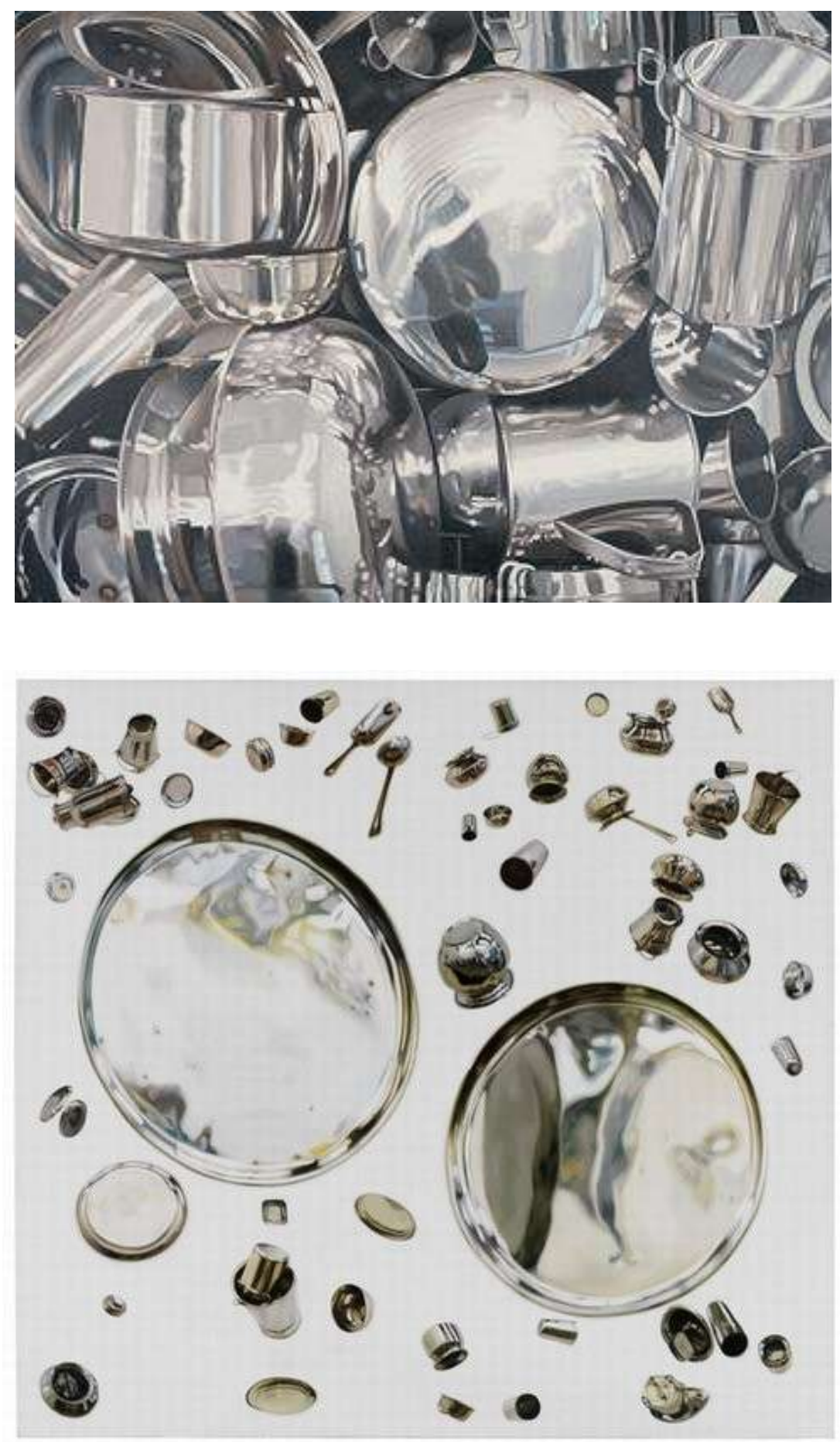


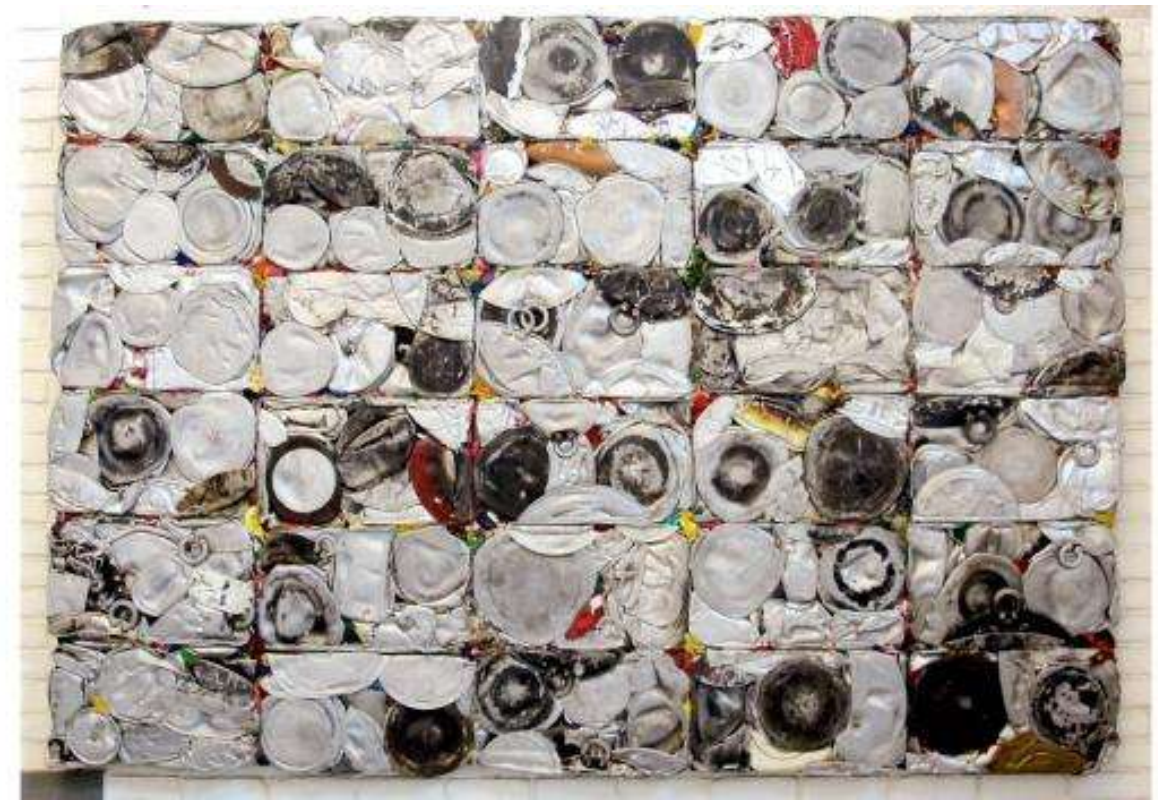

Fig 3 Subodh Gupta Cosmos VIII, 2009 Fig 4 Untitled (2015) by Subodh Gupta, in aluminium, fabric and resin Details from Gupta's installation Dada in NGMA in 2014

Gupta's work can be analysed through the lens of Merleau-Pontian phenomenology; looking at the specific quality and texture of the material, the fact that polished steel possesses a sensory quality, and this sensory quality of the steel facilitates a perceptual transformation. Gupta heightens the beauty of these elegantly shaped utensils through his compositional skill. Gupta's early paintings and the gradual transformation of these to sculptural installations aptly captures the transformative potential of painting. The framing and perspectival arrangement heightens the glimmer of the white steel and thus foresees the possibility of a transformation. The transformation manifests itself in the series of paintings titled cosmos exhibited as part of a high profile international shows in London and Berlin by Gallery Houser \& Wirth. The luminous utensils apparently float on a white background aimlessly and scattered. In Cosmos VIII, two steel plates, disproportionally large float at the centre, face up These reflect fragmented shadows of other utensils. Every day utensils becomes a metaphor for the universe. It is easy to get caught-up in the fact that Gupta is painting utensils realistically which is an act of traditional representation, but the moment the utensils are taken out of their context and their sensory qualities are enhanced to allude to star-light, these oeuvres become abstract. It takes creativity to see the potential of the round, crisp shape and glistening color of these utensils and turn, topple, and arrange them into an astral constellation. It is easy to over-look the fact that these steel utensils have some intrinsic qualities that catches the eye, not every other utensil can be arranged and transformed into stars. The sensory quality of steel, its coldness and sharp edges repel and invite the viewer. These objects realistically painted but surrealistically arranged creates an invented perceptual space. In his later works he continues to exploit the visual appeal of glimmering steel surfaces: in sculptural installations and in inventive paintings. The conceptual process of cultural symbolism and the embodied process of perception are closely related in this case. In Subodh Gupta's installation many of the aesthetic qualities of art comes from bodily meaning: coldness, roundness of steel. Plates, pots, glasses and ladles seem to dance in an empty space. The appeal of the materiality being represented - cold steel - doesn't depend on cultural knowledge of the use of stainless steel vessels in Indian culture (many people will have no knowledge of steel utensils from various parts of the world as they'll only have had experience of plastic, ceramic, leaves, clay 
etc.). But even to these people the metallic touch will have a specific connotation. People how have intimate knowledge of Indian middle-class family ritual may make more culturally rooted interpretation of the works such as the cosmos of an Indian women's kitchen, of a certain class and culture, that they are scrubbed and stored openly in most houses, not cold but closer to the hearth, the cooking. It can also be inferred that these steel containers make musical sounds familiar to many. The interesting arrangement emanates metallic clinks like a well-tuned gong or a bell. The sound these utensils evoke would be shriller than what is heard in temple or monasteries. In these images visual auditory and tactile mingles. Most of the reviewers of Gupta, concentrate on the Indian-ness in his work, though one critic does notice the poetry in Gupta's work. Maxwell Williams write that only a poet can see galaxies in something as pedestrian as pots and pans stacked in the kitchen sink. Maxwell Williams (2015) in Cultured magazine. While describing Gupta's works.

In visual art, poetic quality is generated from how sensory elements are arranged rhythmically. Connecting the sensuous world with poetry is a key tenet in phenomenological theories. But interpreting his work through the lenses of phenomenological aesthetics can open up new horizons of interpretation.

Two concepts proposed by Merleau-Ponty's theory of perception can shed light into illustrating the appeal of Gupta's oeuvre- Merleau-Ponty's theory of perception looks upon vision as a co-ordination of different senses. This sensory coordination takes place before/or simultaneously when we come to a conceptual understanding of the world around us. This "prereflective" or "pre-conceptual" state is a breeding ground for creative/generative thought process. This pre-conceptual understanding being a unified field makes the world of experience intelligible and meaningful. The body Merleau-Ponty describes in his essay is not "the body as a chunk of space or a bundle of functions but that body which is an intertwining of vision and movement". Merleau-Ponty (1993: 24) Merleau-Ponty's notion of the pre-conceptual is not akin to the idea of pre-conceptual proposed by the mechanistic psychology of his time. According to scientific psychology of Merleau-Ponty's time "pre-conceptual" is the passive reception of sensory data by a living organism. For Merleau-Ponty the supposed passivity of the senses is fraught with generative possibility. Fusion of the different senses (including kinesthetic senses) in our pre-conceptual bodily awareness is tinged with intentionality (Carman, 1999). Our sensual and bodily experiences of the world become meaningful perceptual unity by virtue of the understanding of what we can or cannot do within the space we live in and the objects we come into contact with. That is how intentionality forms a big part of our lived experience of the world. Most of our sensory experiences are felt as "I can" rather than "I think". Our bodily existence is an orientation towards given tasks or the possibility of such tasks. This frame-work has also been termed body-schema by Merleau-Ponty (2004,2008). Our sensory or bodily understanding of the world is an understanding of what our body can do, our perceptual capacity is intimately related with intentionality. We perceive the world around us as frameworks of possibilities: possibilities of sensory and bodily explorations. The body's framework of intentionality or capacity is termed body-schema by Merleau-Ponty. While apprehending Gupta's work, the audience's different sensory modalities fuse. In the fig 3 and fig 4 the viewer's eye sees movement and is able to sense the sharp noise made by two light steel objects. Painting is a visual media but this painting evokes tactile impression through depiction of gleaming, white steel that moves and evokes sound. In other words, this painting encourages a direct pre-cognitive or pre-conceptual engagement where bodily senses become fused. In reality one cannot touch the utensils and feel their cold-ness, but the alternate image of the body that belongs to the world of aesthetic perception can do precisely that. The ability to sense movement in the static image and relate it to the cosmic dance of the 
astronomical figures is the viewer's pre-conceptual and body-schema. However, Gupta's newer works seems to have lost this simple and direct appeal to sensuality due to its overt reliance on cultural symbolism.

Brodsky (2014) has cited Marwan Karaidy who characterizes a new trend in commodification of cultural identity "as a global, commoditized hybridity, or a superficial multiculturalism in which icons of East and West are "pasted" together"(Karaidy 2005, 127). In contrast, in my analysis, I have focused on the material aspects of Gupta's work. And this analysis is not a testimony asserting that Gupta's work is the unique work of genius, neither does it validate his whole body of works in terms of artistic accomplishment. My aim is to bring attention to the materiality of Gupta's art. Gupta is one of the most visible and economically successful artists from India. The value of Gupta's work may also be categorized as symptomatic of the randomness of market economy that validate art-works. Answer to this debate lies outside the scope of this thesis. But as I hope to illustrate, creative processes lie at the heart of some of his early works and that even within the prominence of cultural symbolism, sensory and perceptual aspects of material can open up new horizons of perceptual experience.

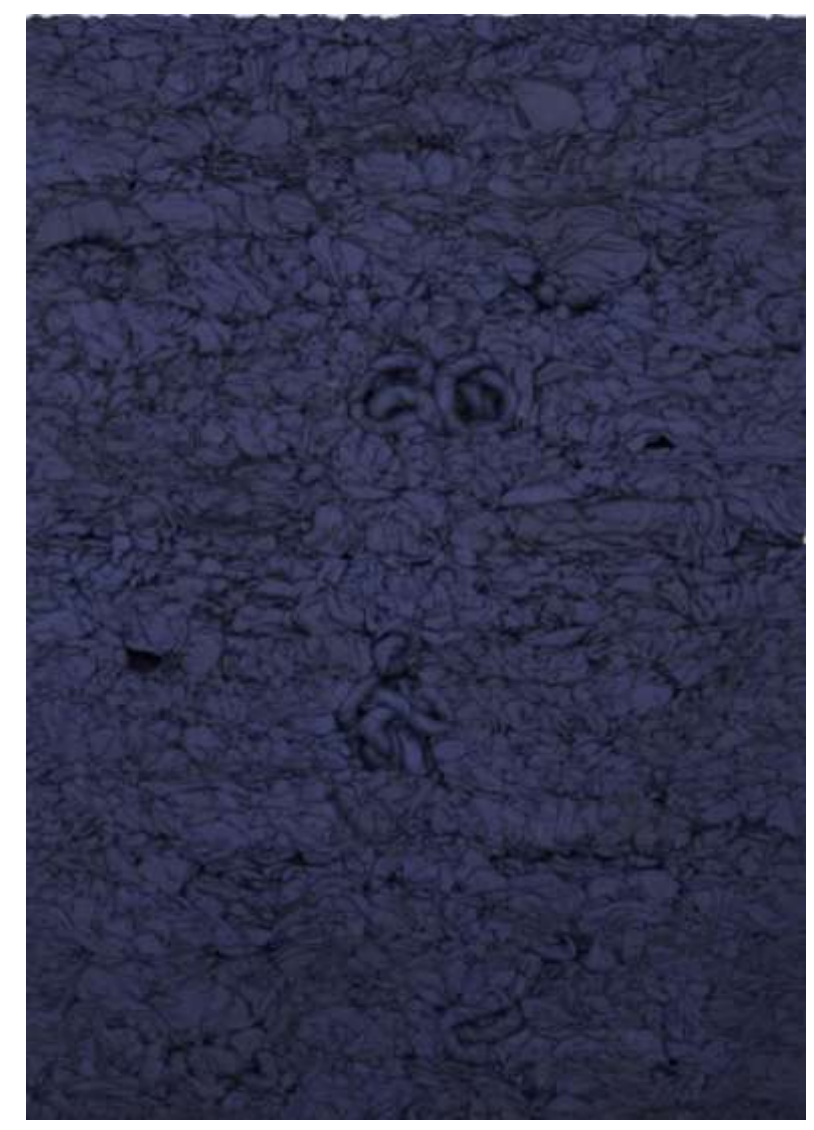

Fig 5 Manish Nai.Untitled, 2013, indigo jute cloth, wood

Some younger painters from India are keeping the trend of material exploration alive. One painter whose works illustrates the transformative process of material manipulation in the creation of conceptual and contemporary paintings is the work of Mumbai based artists Manish Nai (b. 1980). Nai is born and based in Mumbai. There is not a lot of distinct traditional cultural symbolism operative in their work. His works encompasses paintings, sculptural works, and installation. His paintings are distinct in their ability to incorporate sculptural and photographic 
elements. But these works remain and displayed as paintings. His jute canvases deserve special attention in the context of this paper.

These are framed canvases where folded and crumpled sheets of dyed jute perceptually transforms into delicate gestural brush-strokes. Jute is a lowly material in Indian cultural context. Used extensively in packaging industry and agricultural storage properties. Historically Jute has enormous cultural and political significance in Indian subcontinent and it could be said that appropriation of this material in framed canvas is a commentary on class-politics. But also the transformation of jute into a painted surface is achieved through a process of material manipulation. Nai with his sensuous openness as an artist would have seen the possibility in the texture of jute, the possibility that it can be transformed into a baroque surface. He picked the dark indigo dye and with his skilled gesture created a painterly surface. The embodied and tactile aspect of Nai's work have been very well captured by curator and writer Ranjit Hoskote, (2015) in the Curatorial text accompanying Nai's work in Gallery Mirchandani + Steinruecke Hoskote proposes that Nai's works are shaped by two distinct contrasting gestures and their interplay, Nai's attentive assimilation of different materials bear testimony of his experience in the world. The interplay of these elements are expressed in the poetics of form. ": the scratch and the fold. If the scratch incarnates the more austere, minimalist, drawing-oriented aspect of Nai's work, the fold embodies its more opulent, baroque, properly sculptural aspect" (Hoskote 2015) Hoskote aptly captures the link between the experiential world of the artist, the materials he picks and his artistic gestures. Nai's uneven canvases are distinctly tactile, viewers' eye delights in the possibility of moving their finger through the folds. At the same time, they are aware these folds belong to the aesthetic space of a framed painting and out of reach of bodily explorations. Tactile and visual fuse in the experience of looking at these painting.

We can see similar exploration in the work of contemporary Indian artist Tanya Goel (b. 1985). Her works would be categorized loosely as minimalist painting in the style of geometric abstraction. One series of her painting is particularly worth analyzing in the light of the sensory appeal of material.

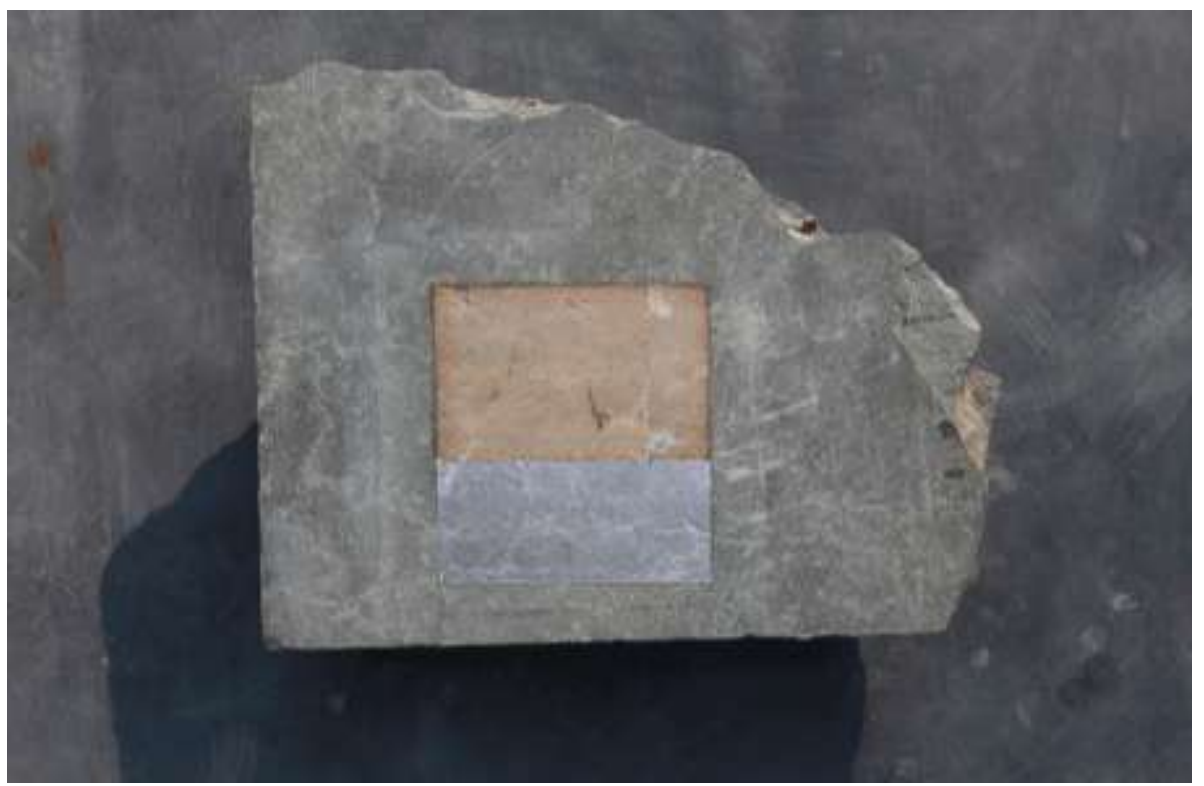

Fig 6 Tanya Goel, Aluminum, Silver Leaf Studies \#4 Aluminum, lead, silver foils on compressed concrete 
This series is a testament to the process of meaning making through material. The curatorial statement accompanying her works in Shrine Empire Gallery states that she experiments with different materials and pigments; aluminum, charcoal, concrete, soil, glass etc, many of these she collects from demolition sites and transforms into pigment. "...She is interested in the textures of her pigments as well as their colors, which is a direct result of how they reflect light" This sensory experiment with the materials is the process by which she realized her works which at the end of the process become formal paintings. But these still preserve the identity of the material. For example, Fig 6 is a concrete chunk with scratches on its surface, but the metallic leaves pasted on its surface accentuate these scratch marks, transforming these into delicate traces of pigments usually seen on the surface of canvas. The sharp, straight geometric shape of the foil also stand in contrast to the uneven broken corner of the concrete chunk but these two elements balances each other and becomes a metaphor for the tension between randomness and mathematical precision. The story is told by juxtaposing different materials. The concrete blocks bear testimony of the rapidly growing urbanization process of Indian cities. Goel herself ventures into these sites and collects the material. Goel's embodied presence in these sites have facilitated her artistic decision of using these materials and transforms these into formal paintings.

There are many other your painters from South-East Asian diaspora creating innovating works of art through embodied explorations of their immediate experiments. These artists are influenced by different trends in contemporary art word and they have incorporated the cultural influence and personal experience in their own individual style. If we look into the concept of style as defined by Merleau-Ponty, discussed by Linda Singer (1993), artists are not consciously aware of their individual style but their unique style is an expressive way of connecting to the world around them. The artists discussed in this paper has forged their artistic style as an expression of their lived experience. For Begum it's the colour of Bollywood, her experience in the waterfront, in the same way as Subodh Gupta transformed the everyday lowly utensils into otherworldly constellations, Nai and Goel has transformed lowly materials such as jutes and broken concrete slabs into delicate painterly installations. In all of these works different sensual experiences come together in an integrated work of art: The fusion of different sense modalities is an important element of Merleau- Pontian embodiment. Exploration of the immediate environment and picking out materials that are culturally important and also possess interesting sensory qualities is an important part of the artistic process. These artists transform materials through sensory explorations. And these creative transformations are embodied craft articulations as well as conceptual expressions. In the present paper terms such as body-schema, pre-reflective or pre-conceptual mind, unity of the senses is brought into the vocabulary of art- theory, and criticism, in order to show how a phenomenological lens can bring new insight into theorization of contemporary painting.

\section{References}

“Tanya Goel: Bio", Shrine Empire Gallery http://www.shrineempiregallery.com/artist/tanya-goel/ accessed in Feb 2020

Adajania, N. (2016) Thirteenth Place: Positionality as Critique in the Art of Navjot Altaf, Delhi; Guild Art Gallery

Biswas, A. (2016) "Review: Invisible reality" Glass Magazine review of Subodh Gupta’s show 'Invisible Reality' at Houser and Wirth. 
11 The Phenomenal and the Cultural in Contemporary Paintings from Indian Diaspora

Brodsky, D. (2014) Crossing Boundaries: The Art of Anjali Deshmukh and RohiniDevasher (In Collaboration with the Artists) Santa Cruz: University of California

Carman, T. (1999) “The Body in Husserl and Merleau-Ponty” Philosophical Topics, 27, No. 2,

Crowther, P. (2009) Phenomenology of the Visual Arts, Stanford CA: Stanford University Press

Elkins, J. (2000) What Painting Is, NY: Taylor \& Francis

Goldstein, M. (20016) "Supercurator Hans Ulrich Obrist on What Makes Painting an Urgent Medium Today”, Artspace,

Hoskote, R. “Artist's Profile Manish Nai” in GalerieMirchandani + Steinruecke http://www.galeriems.com/artist-details.php?id=15 accessed in Sep 2018

Merleau-Ponty, M. (1993) Eye and Mind. In Johnson, G. (Ed.). (1993). The Merleau-Ponty Aesthetics Reader: Philosophy and Painting (pp. 121- 149).

Merleau-Ponty, M. Cézanne’s Doubt.In Johnson, G. (Ed.). (1993). The Merleau-Ponty Aesthetics Reader: Philosophy and Painting (pp. 59-75). M. Smith (Trans.). Evanston, Illinois: Northwestern University Press. (Original work published 1945)

Merleau-Ponty, M. (2008) Phenomenology of Perception: C. Smith (Trans.) New York and London: Routledge (Original work published 1945)

Merleau-Ponty, M.(2004) The World of Perception, NY:Taylor \& Francis,

Savanshukha, P. "A Return to the Senses" The Hindu published in October 2019 https://www.thehindu.com/entertainment/art/a-return-to-the-senses/article29824502.ece accesed in Fed 2020

Shankar, A. “Artist Rana Begum's solo show is on view at Jhaveri Contemporary, Mumbai” Architectural digest September 2019 https://www.architecturaldigest.in/content/mumbai-rana-begum-jhavericontemporary/ accessed in Feb 2020

Singer, L. (1993)“Merleau-Ponty on the Concept of Style” in ed. Johnson, G. The Merleau-Ponty Aesthetics Reader: Philosophy and Painting. Evanston, Illinois, Northwestern University Press: 233-244

Smith, J. (2005) "Merleau-Ponty and the Phenomenological Reduction”. Inquiry, 48 no 6: 553-571

William, M. "Subodh Gupta" in Cultured Magazine, Miami Fl (February/March 2015): 160-163.

Asmita Sarkar is Faculty member at the Srishti Institute of Art. She is a practicing artist and her research interests include contemporary drawing $\mathcal{E}$ painting, art-science collaboration in art $\mathcal{E}$ design, and phenomenological aesthetics. She has published peered reviewed articles in Tracey and Drawing Research Theory and Practice amongst other, and currently working on her practice based PhD (registered in Manipal Academy of Higher Education,) thesis on phenomenology of contemporary painting. Email: asmita.sarkar@srishti.acin 